\title{
Race, whiteness and transformation in the Promise Keepers America and the Mighty Men Conference: A comparative analysis
}

\begin{tabular}{|c|c|}
\hline $\begin{array}{l}\text { Author: } \\
\text { Siphiwe Dube }\end{array}$ & \\
\hline $\begin{array}{l}\text { Affiliation: } \\
\text { 'Department } \\
\text { Theology, Facu } \\
\text { Theology, Univ } \\
\text { Pretoria, Sout }\end{array}$ & $\begin{array}{l}\text { f Practical } \\
\text { llty of } \\
\text { versity of } \\
\text { Africa }\end{array}$ \\
\hline $\begin{array}{l}\text { Project leader } \\
\text { Project numbe }\end{array}$ & $\begin{array}{l}\text { : Y. Dreyer } \\
\text { er: } 2546930\end{array}$ \\
\hline $\begin{array}{l}\text { Description: } \\
\text { Dr Dube is par } \\
\text { the research p } \\
\text { Studies and Pr } \\
\text { Theology Theo } \\
\text { directed by Prc } \\
\text { Dreyer, Depart } \\
\text { Practical Theol } \\
\text { Theology, Univ } \\
\text { Pretoria. }\end{array}$ & $\begin{array}{l}\text { ticipating in } \\
\text { roject, 'Gender } \\
\text { actical } \\
\text { ry Formation', } \\
\text { of. Dr Yolanda } \\
\text { tment of } \\
\text { logy, Faculty of } \\
\text { Jersity of }\end{array}$ \\
\hline $\begin{array}{l}\text { Corresponding } \\
\text { Siphiwe Dube, } \\
\text { siphiwe.dube }\end{array}$ & $\begin{array}{l}\text { g author: } \\
\text { @up.ac.za }\end{array}$ \\
\hline $\begin{array}{l}\text { Dates: } \\
\text { Received: } 10 \mathrm{~N} \\
\text { Accepted: } 25 \\
\text { Published: } 18\end{array}$ & $\begin{array}{l}\text { May } 2016 \\
\text { Aug. } 2016 \\
\text { Nov. } 2016\end{array}$ \\
\hline $\begin{array}{l}\text { How to cite th } \\
\text { Dube, S., } 2016 \\
\text { whiteness and } \\
\text { transformation } \\
\text { Promise Keepe } \\
\text { and the Might } \\
\text { Conference: A } \\
\text { analysis', HTS } \\
\text { Studies/Theolc } \\
72(1) \text {, a3476. } \\
\text { org/10.4102/h }\end{array}$ & $\begin{array}{l}\text { is article: } \\
\text {, 'Race, } \\
\text { n in the } \\
\text { ers America } \\
\text { y Men } \\
\text { comparative } \\
\text { Teologiese } \\
\text { ggical Studies } \\
\text { http://dx.doi. } \\
\text { tts.v72i1.3476 }\end{array}$ \\
\hline $\begin{array}{l}\text { Copyright: } \\
\text { (c) 2016. The A } \\
\text { Licensee: AOSI } \\
\text { is licensed und } \\
\text { Creative Comn } \\
\text { Attribution Lic }\end{array}$ & $\begin{array}{l}\text { luthors. } \\
\text { IS. This work } \\
\text { der the } \\
\text { nons } \\
\text { ense. }\end{array}$ \\
\hline Read online: & \\
\hline 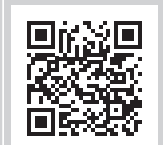 & $\begin{array}{l}\text { Scan this QR } \\
\text { code with your } \\
\text { smart phone or } \\
\text { mobile device } \\
\text { to read online. }\end{array}$ \\
\hline
\end{tabular}

This article takes cue from Sarojini Nadar's article analysing the Mighty Men Conference (MMC) in South Africa as a case study of masculinism, where the author makes some passing comparison between Promise Keepers in America (PKA) and the MMC in South Africa. This article investigates the specific ways in which PKA and MMC are ideologically similar, while also evaluating how their differences accrue dissimilar results with respect to their missions on race reconciliation. The article argues that despite their shared religious similarities as evangelical Christian men's organisations and perceptions regarding the 'crisis in/of masculinity', race discourse plays different roles in the ministries of PKA and MMC. The key observation arising from addressing this discourse is that in the context of PKA, the organisation's institutional focus on race translates itself into discussions and debates about race reconciliation amongst the various racialised men of the movement as part of the organisation's work of self-transformation. However, such talk, although present at the individual level to some extent in the MMC, is absent at the institutional level. The absence of such discourse is especially problematic given the visibility of race in public discourse in South Africa, in general, and also points to a masked refusal to give up white male privilege in the post-apartheid public sphere.

\section{Introduction}

In her 2009 article analysing the Mighty Men Conference (MMC) in South Africa as a case study of masculinism, ${ }^{1}$ Sarojini Nadar makes some passing comparison between Promise Keepers America (PKA) in the USA and the MMC in South Africa. Taking cue from Nadar, this article presents some findings on not only the specific ways in which PKA and MMC are ideologically similar, but also how their differences accrue dissimilar results with respect to their missions on race reconciliation. Specifically, this article argues that despite their shared evangelical Christian background and perceptions regarding the 'crisis in/of masculinity', race discourse analysis plays a different role in the ministries of PKA and MMC. The key observation being that in the context of PKA, the organisation's institutional focus on race translates itself into discussions and debates about race reconciliation amongst the variously racialised men of the organisation as part of its work on self-transformation. However, such 'race talk', although present at the individual level to some extent in the MMC, is absent at the institutional level. The absence of such discourse is especially problematic given the visibility of race in public discourse in South Africa, in general, and also points to a masked refusal by certain groups of 'white men' to give up white male privilege in the diverse post-apartheid public sphere. By highlighting race and gender, the article aims to bring these two critical aspects of diversity discourse into particular focus for religious contexts, specifically Christian men's organisations.

In analysing this gendered difference in engaging race, racialisation and racism between PKA and $\mathrm{MMC}$, the article foregrounds the belief that it is important to examine how the discursive performance of masculine power in post-apartheid South Africa has the potential to not only reify normative discourses of masculinities, but also provide alternative discourses of masculinities that directly alleviate the gendered discursive and material inequalities that still plague the society through engaging the language of critical religious discourses of masculinities. Moreover, by focusing on Christian men's organisation, it is also the article's argument that religious organisations still have an especially important role to play with regard to gender norms

1.Nadar uses a definition of masculinism taken from Chris Haywood and Mairtin MacGhaill (2003), Men and Masculinities, Open University, Buckingham, 10: 'Masculinism is an ideology that stresses the natural and inherently superior position of males, while serving to justify oppression and subjugation of females. This ideology of males being naturally more powerful, competent, successful and fundamentally different from females is one that can be located in various historical periods'. 
transformation as they continue to have a large sociopolitical influence due to being a core part of an active civil society in South Africa. While this last observation regarding religion in South Africa is a generally accepted claim, the significant role played by religious discourse in perpetuating the refusal to give up white male privilege, on the other hand, is an avenue still to be fully explored, even though religion (specifically Christianity in this context) is assumed to play a significant role in South African public discourse in general.

\section{Theological context: Shared evangelical ideology}

A close analysis of the two organisations' mission statements and theological perspectives shows that despite their geographical distance, these two organisations share not only similarities as evangelical Christian men's organisations but also perceptions regarding the 'crisis in/of masculinity'. Consequently, PKA and MMC also share very similar missions and aims with respect to changing Christian men's lives, both locally and globally. Moreover, as a clear sign of endorsement, PKA has recently welcomed MMC founder and leader Angus Buchan to a few of its events in the USA to date. In other words, there is a certain sense in which the Christian Religious Right discourse is gaining a global purchase beyond simply localised contexts, and it is important to examine the similarities as part of also figuring out how to harness this religious network for positive social transformation purposes.

Firstly, a substantive and notable discursive similarity between the MMC and PKA can be seen in the conceptualisation of their respective missions. Buchan describes the MMC's mission in personal terms this way:

In 2003 the Lord laid it clearly on my heart that I need to mentor young men. The message the Lord gave me was to teach men to be: Prophet - the man who leads his family. Priest - the man who heads up his home spiritually. King - the man who is the primary bread winner of his home. Your fellow harvester in Christ, Angus Buchan. (Buchan 2014:np)

Moreover, in his book, The Mighty Men Journey (2012) which Buchan considers 'to be the absolute, undeniable, authentic account of what happened' regarding the MMC, he makes the following statement with regard to the organisation's mission: 'If we had to sum up the Mighty Men phenomenon in one word, it would be "passion," seeing men passionate for the King, for God' (pp. 11, 79). On the other hand, the mission of PKA is given as 'to ignite and unite men to become warriors who will change their world through living out the "Seven Promises" to God, their families, their fellow man and community' (The Promise Keepers America 2008). From these statements, it can be gleaned that the shared mission of PKA and the MMC is to bring men closer to God, by dint of which they can reclaim their rightful place as leaders of their families and, consequently, have an impact on their communities. In both the PKA and MMC there is emphasis placed on uniting and equipping men to change not only their individual lives but also those of others, especially their families.
Moreover, there is a detectable confrontational tone in both organisations' stated missions. While highlighting devotion, both PKA and MMC also emphasise warriorship, thus invoking the language of battle. As Nadar (2009) notes in affirmation of this observation:

What is also evident in Buchan's rhetoric is a language of conquest and might and strength. Nowhere is this more clear of course, than in the choice to name these meetings the 'Mighty Men's Conference [sic] ... (p. 555)

In fact, Buchan (2012) defends the language of conquest when he notes that,

If you read into the title, though, you will see that it refers to King David's mighty men, men who were prepared to die for the cause, for each other and for King David, their leader. (2012:18)

Similarly, the often quoted statement by Tony Evans (PKA leader) that men should take back leadership and not ask for it goes far in demonstrating how deep-set the rhetoric of conquest, might and strength is in both these organisations' self-construction. In laying claim to such a battle or warrior mentality, both PKA and MMC conform to a shared ideology: an ideology of conquest and male leadership based on aggressive reclamation.

The second of the key aspects of the shared theology between PKA and MMC that is important to highlight as part of underscoring the interconnectedness of a global Christian men's movement that stands in sharp contrast to the liberal public discourses prominent in either country is the shared beliefs rooted in the evangelical Christian tradition. John G. Stackhouse, Jr. argues that:

evangelicalism is rooted in the 18th-century transatlantic revivals that typically held to the unique theological authority of the Bible, believed a common core of Protestant doctrine regarding God and salvation, cultivated personal piety, and bore witness to the gospel, especially through evangelism but also in works of charity. (2011)

In a similar fashion, as Kennedy Owino notes, South African evangelicalism, while placing emphasis on neoPentecostalism, also emphasises 'the forgiveness of sin and personal salvation in Jesus Christ, the infilling of the Holy Spirit, and a life marked by prayer, devotion and practical holiness' (2012:71-72). While it should be noted that there are differences between the US and South African forms of evangelicalism, both PKA and MMC can be said to be rooted in a shared understanding of the core traits of 'a universal' form of evangelicalism.

For example, bullet points five, six and seven of the nine in the description of the MMC's 'simple message' highlight the key aspects of personal salvation, the authority of the Bible and piety:

We are not interested in personal opinions, only God's opinion. Everything they speak, must be qualified by Scripture. No-one is interested in quotations from men who have no standing in the sight of God. (The Mighty Men Conference 2014) 
Actually, in further affirmation of his evangelicalism, Buchan goes on to state in his book that, 'I am a fundamentalist through and through. God said it, I believe it, and that settles it.... Men want to follow the truth because the truth always stands out' (2012:152). This truth is salvation and is accessible only through the Bible, thus demonstrating one of the highlighted core traits of evangelicalism. Similarly, PKA highlights the authority of the Bible aspect of evangelicalism by advocating that:

Since the birth of Promise Keepers, a focus on the Word of God has been central. When 'The Seven Promises of a Promise Keeper' was created, the very first promise was grounded on this necessary truth. Promise One of the Seven Promises is: A Promise Keeper is committed to honouring Jesus Christ through worship, prayer and obedience to God's Word in the power of the Holy Spirit. Everything that Promise Keepers does centers on this central truth - obedience to the Word of God. (The Promise Keepers America 2008:n.p.)

As evangelical movements then, both PKA and MMC share in the core traits of evangelicalism identified above, pointing to an interconnected understanding of what each organisation is doing within its own particular context.

The above notwithstanding, it is important to note that there is still a lot that separates PKA and MMC as evangelical Christian men's organisations in terms of geography, political context and their construction of the relationship between state and religion. However, both organisations have also, nonetheless, arisen within a 'glocal' context defined by a similar process generally referred to as the 'crisis in/of masculinity'. While perhaps familiar to most readers of this article, it is important, nevertheless, to briefly describe this 'crisis' situation as a way of further situating the article's analysis of PKA and MMC.

\section{Historical context - 'Crisis in/of masculinity'}

Various scholars and public critics of gender in both the USA and South Africa have highlighted the key elements of the traditional narrative of the 'crisis' by noting how, for example, in the post-sixties' US economic, social and cultural developments 'had gradually eroded the grounds on which dominant masculine ideals had once been based', as Judith Newton argues (2005:8). This ground of dominant ideal of masculinity, as she further notes, had 'implicitly assumed men's right to greater power and privilege than women' (Newton 2005:8). However, the challenge of this ground through a combination of 'growth in gender consciousness, an increase in the percentage of women in higher education, greater access for some women to traditional male-dominated forms of employment, laws against gender discrimination' led to the perception that men were being deprived of authority, and, worst of all, men lacked a well-defined enemy and a clear frontier to which they could direct their manly prowess (Newton 2005:8). In further support of this argument, Hamilton Carroll notes that: 'In Hollywood feature films, prime time television shows, self-help books, newspaper columns, conservative talk radio, news magazine cover articles, and presidential speeches the discourse of masculinity in crisis is clearly evident' (Carroll 2011:2).

In South Africa, Rosemary Jolly (amongst a few others) has observed that:

at the very moment the Constitution appears to a variety of men to imply, through its provisions on gender, that heterosexual men have been and are in privileged positions of power, many men who identify as heterosexual experience their current reality as one in which their power is being increasingly diminished. (2010:117)

This is a point made by several observers of practices of masculinity in post-apartheid South Africa. Much of this scholarship links gender-based violence against women in South Africa directly with this 'crisis in and/or of masculinity' by noting, for example, how ironic but not surprising it is 'that the liberalisation of sexuality appears to have been accompanied by an increase in gender violence' (Walker 2005:228). Interestingly enough, in much of the scholarship dealing with this topic it is mostly black men who are identified as most responsible for this violence. The point here, however, is not to examine the 'crisis' discourse indepth, but to briefly show how the notion of the 'crisis in/of masculinity' is a prevalent discourse in both the US and South African contexts in question. Carroll attests to this global nature of the 'crisis' when he notes that, discourses of the 'crisis of masculinity is a local (i.e., nationally specific) response to a global phenomenon', 'where profound global transformations are still commonly felt, negotiated, and understood' at the national level (2011:3).

In other words, in both countries men are said to feel that they no longer possess 'exclusive ownership over the social roles once held as bastions for establishing and performing patriarchal' hegemonic masculinity as a result of change in national social, economic and political landscapes (Atkinson 2011:5). While there are some men and women who've seen this as an opportunity for men to break 'new ground by engaging arguments relating to how men themselves, and not only women, are deeply scarred and alienated by stereotypical or ideal-typical notions of maleness' (Atkinson 2011:1), much of the response has been mixed. That is to say, the rise of religious men's organisations such as PKA in the USA and MMC in South Africa (as specifically national responses to the perceived 'crisis of/in masculinity' in either country) can, therefore, be located within a broader transAtlantic history of the perceived 'crisis'.

Such a conclusion regarding the linked nature of the process of thinking about the 'crisis in/of masculinity' in both countries should not be surprising, especially given the ways in which the imperialist and colonial experiences that are part of and parcel of global masculinities discourses today are informed by the centrality of whiteness as a discourse of masculine power - a fact that cannot be denied in either the South African or US context given the embeddedness of the intertwined institutions of imperialism 
and racial segregation in each country's nationalist narratives. This connection is even more acute when one also takes into account the very similar ways in which both PKA and MMC take up the idea of 'male romance' in their processes of engaging men to re-imagine masculinities in the light of Christian norms as part of responding to the perceived 'crisis in/of masculinity'.

\section{The trope of male romance in Promise Keepers America and Mighty Men Conference}

According to Newton, 'male romance' encompasses men separating from women, creating ritual space, risking intimacy and disclosure, and undergoing a rebirth through the agency of male figures or other men (2005:15). 'Male romance' takes the ideas of heroic deeds, adventure and romantic love from the traditional romance genre and reinterprets them in the context of contemporary masculine identity formation. In the case of PKA for example, the first three promises - (1) to honour Jesus Christ through worship and prayer; (2) the commitment to pursue vital relationships with other men; and (3) the commitment to practise spiritual, moral, ethical and sexual purity - all speak to individual men and their personal spiritual growth as Christians. Indeed, PKA men are counselled to observe these promises or points of fellowship through the organisations' conferences, which are large gatherings that bring men together for a time of encouragement and being challenged in various areas of being a man.

In the case of the MMC men, Buchan highlights the type of male romance that takes place at MMC conferences by noting that the reason why only men can come to MMC is because:

there are times when men need to be together. They need to identify with each other, to take the mask off and be themselves. They need to be allowed to cry in each other's arms, to be allowed to laugh and they need to be able to talk about things which pertain to men. (2012:111)

Moreover, as Buchan further notes, in addition to being fine for men to cry and laugh, they also should 'go hunting, fishing and play sport, because those are things that men do' (2012:95), but not women. By gathering in men-only conferences or rallies, both PKA and MMC men engage in a male romance context of re-imagining masculinity in an evangelical Christian-centred way. While these conferences are varied, they are, nonetheless, national events meant to bring together large numbers of men into one place - usually big football stadiums in the USA or the Greytown farm in KwaZulu-Natal for MMC until 2010, after which the conferences have been held in various places across the country such as the Karoo in 2014.

Here, men are separated from women, create ritual space through communal prayer, risk intimacy and undergo a rebirth through the agency of high-profile Christian male figures. The events usually feature high-profile Christian ministers as main speakers, who serve as agents that help the men through their transformation process. In the case of the MMC Buchan has served as the high-profile figure for all the major conferences. During the conferences men are encouraged to set their personal relationships with Jesus right by taking risks (heroic deeds) and participating in an adventure that will be rewarded with the most satisfying relationship they have experienced yet. The unstated invocation is that men can achieve the kind of transformation they seek primarily by attending one of the Promise Keepers or MMCs and in the company of other men. In this sense, time with other men is deemed important for masculine gender identity formation and transformation, and it is important that men pursue such a project in the company of other men. Even Buchan's description of the Mighty Men phenomenon as a journey is reflective of the male romance narrative trope - a journey of the hero's self-discovery.

What is interesting to note is that the men 'in or of the crisis' in these two organisations' discourses are assumed to stand for a generic US or South African experience, but on close analysis this experience is actually premised on a very specifically white masculine romance or regulatory fiction (even while admitting variety in the category of whiteness itself). As Newton (2005) notes with respect to race and masculinities in the USA:

various forms of purely fictive and concretely realised male romance have played a central role in U.S. history, where they have functioned to help reproduce and sustain dominant ideals of masculinity that were based on the implicit belief that economic, gender, sex, and race privilege constituted true manhood for white, property-owning men and that the latter represented the U.S. nation as a whole. (p. 33)

By privileging white masculine ideals, the men of PKA, and MMC in South Africa by comparative extension, promote a particular narrative about gender and race that also figures prominently as a carrier of unstated values and norms that are then consumed through various discursive means and taken to be normative. Specifically, as Kimmel argues in another context: white masculinity in the USA in the current era has placed emphasis on aggrieved entitlement - 'a gendered emotion, a fusion of that humiliating loss of manhood and the moral obligation and entitlement to get it back' (2013:75). For Kimmel, the fusion of gendered aggrieved entitlement with Right-wing politics finds the best resonance in evangelical Protestant, Pentecostal and other radical Christian men's organisations (2013:243).

In the case of South Africa, du Pisani, Nadar and Kennedy Owino have all highlighted the appeal of MMC to white men (both English and Afrikaans speaking). All three scholars point to the perceived sense of loss of power for Afrikaner men in particular as a main reason for their flocking to the MMC. That is, given the disillusionment with the current sociopolitical condition, albeit read in theological terms, du Pisani argues that Buchan succeeds by

letting his message resonate with the deepest needs of a relatively large section of the conservative-minded white male population. 
This fact is evident from the massive crowds that flock in increasing numbers to his Mighty Men gatherings. (2014:6)

Where, of the number of attendees provided earlier, over $80 \%$ of the men attending MMC gatherings are predominantly white, Afrikaans and English-speaking South Africans (du Pisani 2014:6; Nadar 2009:557; Owino 2012:72). Moreover, even in the visual representations of the organisation's media outlets, including the Facebook page and Buchan's book, the majority of those pictured are white men. This visual dominance of white men can be read as simply representational in the sense of documenting what already exists. However, this article's perspective is that it is also representational in the sense of representing white male power in a public sphere, a sphere perceived to be largely against white males in the current milieu.

This appeal to Christian religious language in order to reclaim white masculine power under the guise of servant leadership should not be surprising, especially if we take Kimmel's argument into account that the fusion of gendered aggrieved entitlement with Right-wing politics finds the best resonance in evangelical Protestant, Pentecostal and other radical Christian men's organisations. That is to say, while neither PKA nor MMC has come out proclaiming to be 'white men-only' organisations, their appeal to this particular demographic group cannot be denied and calls for further interrogation into its implications for the broader project of social transformation with particular respect to gender and race, but not excluding class, as part of analysing the systemic interlocking systems of oppression that still plague both the US and South African societies despite years of social critical theory praxis.

\section{The invisibility of white Christian masculinities}

In the case of PKA, R. S. Lawton II notes in his report for Time Magazine that one of the movement's early organisers (Philips) admitted that:

the organisation is still paying a price for failing to reach out to minorities during its inception. 'We started off with white leaders,' so men of colour were 'the add-on, not the DNA. That was wrong and we got hurt.' The organisation has made major progress since then (1997:58)

In particular, as Philips notes further, over the years PKA has seen a growing number of minorities in both its staff constitution and attendance at rallies (Lawton 1997:58). The language regarding the 'minorities' is very telling with respect to the organisation's self-construction as primarily concerned about white men's experiences. The fact that the whiteness of PKA's men is not stated outright, but assumed to be normative, is not surprising given the ways in which a number of scholars have shown how processes of whiteness make claims to privilege through their self-construction as 'invisible' to a large extent (Frankenberg 1997:1).

For example, in the introduction to their book on the rhetorics of whiteness, Wendy Ryden and Ian Marshall note that: 'as the twentieth century progressed and doctrines of white supremacy diminished, whiteness's hegemony became increasingly reliant on its normative invisibility' (2012:3). In other words, as Richard Dyer also argues that whiteness accrues assets of privilege because these are seen as 'part and parcel of the sense that whiteness is nothing in particular, that white culture and identity have, as it were, no content' (1997:9). However, the truth is that the whiteness claim to having no content is actually how it maintains power by not granting the same privilege of not having content to others identified as 'minorities', 'cultures', 'ethnicities' or just plain 'other'. In this sense, whiteness aims to be understood as just an innocent category that really carries no weight, except that it does and in particularly oppressive ways.

Melissa Steyn, analysing recollections of apartheid experiences in post-apartheid South Africa, has referred to this ability of whiteness to set the terms of knowledge contracts without seeming to do so as the 'ignorance contract'. Where, as she argues, 'Whites have the most to gain from remaining ignorant and are more likely to display a "passion for ignorance" rather than engage with the "difficult knowledge" of complicity in systemic injustice' (2012:12). That it took PKA some time to address the whiteness of the organisation as illustrated above demonstrates the extent to which both the invisibility and ignorance contract are embedded within the institutional cultures of both these organisations. Consequently, attention needs to be drawn to how race has played a crucial role in the ministries of both PKA and MMC.

The key observation arising from addressing this discourse being that: in the context of PKA, the focus on race has translated itself into discussions and debates about race reconciliation amongst the various racialised men of the movement as part of the work of self-transformation. However, such talk, although present (however minimal it is) at the individual level, is absent at the institutional level of the MMC. The absence of such discourse is especially problematic given the visibility of race in public discourse in South Africa in general. In fact, Buchan's only direct reference to race in his book (a key reference for men of the MMC) is rather a quick form of catharsis than a serious engagement with this normative category. He argues that, 'Racialism, which has prevailed in our beloved subcontinent for generations, has been instantly extinguished' (2012:103). This statement completely glosses over the racial tensions that actually still plague South Africa and its men. Arguably, this denial or gloss over is due to a negative construction of other men in South Africa that is made publicly visible, such as that reflected by overrepresentations of black men in studies of gender-based violence and the masculinisation of this violent identity in specifically ethno-racial terms of difference.

\section{What racism?}

However, unlike MMC, which has shied away from any race talk, PKA has taken up the mantle through appropriating the 'male romance' discourse and tried to make race 
discourse, at least at the ambiguous level of the concept of reconciliation, part of the organisation's transformative mission. That is to say, PKA has made race a specific category of analysis for men's transformation within its ministry mandate to men. This is a point attested by both Michael J. Chrasta and Don Deardorff in their analyses of PKA. Chrasta argues that the motive central to the entire PKA is the 'desire to promote justice, defined as reconciliation, in all spheres of a man's life' (2000:26). In the context of the USA, one such sphere is racialised inequality, which has caused divisions in the US populace. In answer, as Deardorff argues, 'no matter what their racial or ethnic identity, PKA is providing a refuge from unhealthy masculine paradigms and a way to heal past divisions' (2000:87). Such direct focus on addressing racial inequality, in terms of reconciliation, as part of the mandate of masculine identity transformation can be further observed in the foci of a few national PKA events. Five national events in the 1990s focused on the theme of reconciliation, where mandates were issued for men to pursue reconciliation across racial and denominational lines: Promise Keepers '92: 'What Makes a Man?'; Promise Keepers '93: Face to Face; Promise Keepers '96: Break Down the Walls and Fan the Flame; Promise Keepers '97: The Making of a Godly Man; and '97 Stand in the Gap: a Sacred Assembly of Men.

Moreover, in fulfilling the sixth of the seven promises, which states that, 'A promise keeper is committed to reach beyond any racial and denominational barriers to demonstrate the power of biblical unity', PKA has remained intentional about addressing the tensions due to race strife in the USA (The Promise Keepers America 2008). As such, the absence of a similar discourse in South Africa's MMC at the institutional level is curious at the least and, at worst, highlights the insidiousness of a racialised and racist understanding of the 'crisis in/of masculinity' that assumes a homogenous population of white men in distress. The MMC, and specifically Angus Buchan, dismisses the significance of race discourse as part of the work of transforming men in South Africa. In fact, Buchan claims that it is of no significance to him that a large number of those who attend his meetings are white farmers. He says, 'I am preaching to South African people. I do not care if I preach to 100000 white people or 100 000 black people ... I preach Jesus, not politics' (Richards 2008). While there are different individual views that differ from Buchan's expressed by some MMC events attendees, as Owino's work demonstrates, it is important to note that these are very marginal rather than central voices to the movement's perception of race relations in South Africa (2012:74-76). Such that, while it is important not to conflate conference attendees with the MMC as an organisation in similar fashion that Cole argues in relation to PKA, it is important not to disassociate Buchan's view from the MMC's as he is the organisation's official representative, and his message is taken up by thousands of men as truth for how they are to live their lives (2000:128).

Arguably then, the MMC's 'race-blind' approach, in general, signals a failure to see the significance of the intersection of race and gender in particular terms for the different men who attend the meetings. Moreover, it further highlights Steyn's argument earlier that whites in South Africa in general have the most to gain by remaining ignorant about race matters. Feminists of colour in the USA and UK warned against a universal woman assumed by the feminist movement in its early days, thereby ushering an age of the movement's selfreflexivity. In a similar vein, by missing the opportunity to engage with the categories of 'man' and 'men' in relation to their roles in the racial construction of 'others', the MMC inadvertently continues to widen the marginalisation felt by white men in South Africa as they are not able to see past their own crisis as similar to or related to that of other men, let alone women.

Actually, by mobilising the very politics of identity that it believes to be responsible for the demise of white male privilege (Carroll 2011:6), the MMC actually erodes the gains made through human rights and women's rights clauses of the constitutional democracy of South Africa. Moreover, the MMC does so under the guise of a religious mandate to take back the country as godly men, which, to anyone familiar with Afrikaner nationalism, smacks of the racist religiopolitical mythology of apartheid promoted by the likes of J. C. Van Rooy in 1944, who was the chairman of the Afrikaner Broederbond. While Buchan is not as explicit in his affirmation of the 'white man's burden', his 'race-blind' approach has the same effect of not interrogating white privilege and simultaneously maintaining it through the process of spiritualising the plight of men in the MMC.

Indeed, while not focusing on race has the advantage of giving reprieve to the fetishisation of this discourse in the South African context, completely ignoring it is not the best response either - especially for a group of individuals who already feel isolated by the discourse of social transformation that is taking place seemingly without 'needing' white men, when before they were the central focus. What the MMC's approach has the propensity to instigate further is the reification of Afrikaner men's specialness, a doctrine that gave rise to apartheid and its attendant problems. As Cornel Verwey and Michael Quayle note in their study of Afrikaner identity in post-apartheid South Africa, 'the construction of the Afrikaner community as embattled and systematically oppressed might provide powerful support for extremism' (2012:551). Of course, one also has to point out that such a perspective is nothing new as apartheid was also based on the construction of the fear of the 'black danger' and elicited a particularly extreme response in the form of the Apartheid State. This is not to mention the basis of this response on similar Christian religious grounds asserting the uniqueness of Afrikaners as the last bastions of civilisation in the little corner of 'uncivilised Africa'.

More importantly, however, and this is the problem that assails PKA to a lesser degree as well, is that organisations such as the MMC miss the opportunity to connect the interrelatedness of gender with other social identity concepts 
or markers. PKA, to some degree, succeeded in getting national traction beyond racial lines because the organisation spoke to both the angry white men and enraged black men. That is, PKA's originality lay in its attempt to expand its masculine transformation work into an anti-racist project (Newton 2005:237-243). This is despite the observation by both Newton and David Gutterman that, 'For all its talk about transcending those boundaries that divide men, PK is emphatic about re-inscribing those boundaries that divide men and women', including heterosexual men from homosexual men (2005:237; 2000:141). By siding with other men concerned with similar issues, PKA was able to garner momentum and effect engagement with masculine identity transformation at the national level with the backing of some women's movements that saw their work as better than the alternatives. Potentially, the MMC could add to the litany of voices decrying the state of masculinity in South Africa if it intentionally expanded its horisons and formed strategic alliances with men from different races doing similar work or concerned with similar issues. They might, as a result, be able to expand the resources available to men to address the question of 'changing masculinities' rather than relying mostly on the discourse of male headship as the panacea to the perceived 'crisis'.

\section{Conclusion}

To get back to where this article began, the rise in the global reach of the evangelical Christian men's movement is indeed a cause for concern and one that requires critical examination, especially if what transpires out of this movement is regressive rather than transformative praxis. The comparative analysis above has shown that in the case of the PKA there are redemptive elements that can be salvaged for application in other contexts such as that of South Africa's MMC. While only a small start, such a comparative analysis as proffered in this article is important in the global context of studying the Religious Right and its related organisations not only for alarmist concerns, but also transformative ones. As an aporetic discourse, religion, and specifically Christianity in this context, has the potential to both reify and question inequality norms in ways that are very effective. The challenge is in being able to harness this capacity for social good in a way that both goes beyond the parochial concerns of the community in question (in this case white men) and, at the same time, does not adversely affect other communities concerned either. PKA seems to have minimally put into effect such a complex programme, but MMC might still be in a tender enough stage to learn from PKA's limitations and listen to the multitudes of men's voices that comprise its conferences - a process that remains to be seen as the organisation reaches growth.

Furthermore, such alliances might help do away with the myth of gendered transformation as only a 'women's issue'. If anything is worth repeating, it is that the 'crisis in/of masculinity' runs through the core of this country and men of all races are party to it in very deep and problematic ways. Therefore, as institutions defining and proscribing ethical and moral values, Christian religious men's organisations might be better able to address this issue if they come at it from all angles rather than from just solipsistic ones. In other words, rather than simply promising mighty things politicians in the country do a lot of that already - these men might actually accomplish something far greater than imaginable within the confines of white farms. This call to strategic alliance (echoing the strategic essentialism of Gayatri Spivak) is not, however, an endorsement of the MMC as a whole, but a reconnaissance moment to re-imagine what a mighty men movement focused on healing past wounds based on racial strife might look like and contribute in terms of gendered norms transformation in a country still reeling from the mighty winds of transition and the ever illusive 'holy grail' of national transformation for all.

\section{Acknowledgements Competing interests}

The author declares that he has no financial or personal relationships which may have inappropriately influenced him in writing this article.

\section{References}

Atkinson, M., 2011, Deconstructing men and masculinities, Oxford University Press, New York.

Buchan, A., 2008, 'Angus Buchan - Dying to live', Joy Magazine, p. 16, viewed 25 March 2014, from http://www.joymag.co.za/mag/16-2008/16-2008-angus.php

Buchan, A., 2012, The Mighty Men journey, Christian Art Publishers, Vereeniging.

Buchan, A., 2014, Mighty Men Conference, viewed 25 March 2014, from http://www. mightymenconference.co.za/

Carroll, H., 2011, Affirmative reaction: New formations of white masculinity, Duke University Press, Durham.

Chrasta, M. J., 2000, 'The religious roots of the Promise Keepers', in S.D. Claussen (ed.), The Promise Keepers: Essays on masculinity and Christianity, pp. 20-29, McFarland, Jefferson, NC.

Cole, R.A., 2000, 'Promising to be a man: Promise Keepers and the organisational constitution of masculinity', in S.D. Claussen (ed.), The Promise Keepers: Essays on masculinity and Christianity, pp. 113-132, McFarland, Jefferson, NC.

Deardorff, D., 2000, 'Sacred male space: The Promise Keepers as a community of resistance', in S.D. Claussen (ed.), The Promise Keepers: Essays on masculinity and Christianity, pp. 76-91, McFarland, Jefferson, NC

Du Pisani, K., 2014, 'Palatable patriarchy? Angus Buchan, the "Mighty Men" and masculinity', paper presented at the European Social Science History Conference, Vienna, Austria, 23-26th April, pp. 1-31, viewed 23 October 2014, from https://conference.socialhistoryservices.org/esshc/2014/userApi/ downloadPaper/579

Dyer, R., 1997, White: Essays on race and culture, Routledge, London.

Frankenberg, R. (ed.), 1997, Displacing whiteness: Essays in social and cultural criticism, Duke University Press, Durham, NC.

Gutterman, D.S., 2000, 'Exodus and the chosen men of god: Promise Keepers and the theology of masculinity', in S.D. Claussen (ed.), The Promise Keepers: Essays on masculinity and Christianity, pp. 133-152, McFarland, Jefferson, NC.

Haywood, C. \& Mac an Ghaill, M., 2003, Men and masculinities, Open University Press, Buckingham.

Jolly, R., 2010, Cultured violence: Narrative, social suffering, and engendering human rights in contemporary South Africa, University of KwaZulu-Natal Press, Scottsville, KY.

Kimmel, M., 2013, Angry white men: American masculinity at the end of an era, Nation Books, New York.

Lawton, R.S., II, 1997, 'God of our fathers', TIME Magazine 50(14), 52-58.

Nadar, S., 2009, 'Palatable patriarchy and violence against wo/men in South Africa: Angus Buchan's Mighty Men's Conference as a case study of masculinism', Scriptura 102, 551-561. http://dx.doi.org/10.7833/102-0-614

Newton, J., 2005, From Panthers to Promise Keepers: Rethinking the men's movement, Rowman \& Littlefield, Oxford.

Owino, K., 2012, “The Mighty Men Conference as a "safe space" for "born again" men to express conflicting masculinities?', Journal of Gender and Religion in Africa 18(2), 65-84. 
Richards, W., 2008, Farmer sees 'revival' in South Africa, Charisma: A Strang Publication, viewed 25 March 2014, from http://www.kcionline.org/news/ files/Charisma,\%20Angus\%20Buchan,\%20December\%202008.pdf

Ryden, W. \& Marshall I., 2012, 'Where has all the whiteness gone? Reading and writing race in a "postrace" era', in W. Ryden \& I. Marshall (eds.), Reading, writing, and the rhetorics of whiteness, pp. 1-10, Routledge, New York.

Stackhouse, J. G., Jr. 2011, Evangelicalism, viewed 16 July 2012, from http://www. jrank.org/history/pages/7169/evangelicalism.html

Steyn, M., 2012, 'The ignorance contract: Recollections of apartheid childhoods and the construction of epistemologies of ignorance', Identities: Global Studies in
Culture and Power 19(1), 8-25. http://dx.doi.org/10.1080/1070289X.2012.672840
The Mighty Men Conference, 2014, Karoo MMC, viewed 25 March 2014, from http:// www.karoommc.co.za/about/the-mighty-men-conferences

The Promise Keepers America, 2008, viewed 18 September 2012, from www. promisekeepers.org/about/pkcorevalues

Verwey, C. \& Quayle, M., 2012, 'Whiteness, racism, and Afrikaner identity in postapartheid South Africa', African Affairs 111(445), 551-575. http://dx.doi.org/10. 1093/afraf/ads056

Walker, L., 2005, 'Men behaving differently: South African men since 1994', Culture, Health \& Sexuality 7(3), 225-238. http://dx.doi.org/10.1080/136910504100 01713215 